\title{
Winner takes all: reconstructing the decapitation of a warrior in Bronze Age China from osteological evidence
}

\author{
Yawei Zhou ${ }^{1} \cdot$ Shuang Lin ${ }^{1} \cdot$ Rangping Qin ${ }^{2} \cdot$ Hui-Yuan Yeh $^{3} \cdot$ Qun Zhang ${ }^{3}$ (I) \\ Received: 16 January 2020 / Accepted: 11 August 2020 / Published online: 23 August 2020 \\ (C) The Author(s) 2020
}

\begin{abstract}
Decapitation is an ancient practice in Asia with inadequate research. The present study reports on the osteological examination of a headless skeleton excavated from a high-status tomb in Chu State style dating back to the late Warring States Period (ca. 3th century BC) in Lu'an, Anhui, China. The individual is identified as a victim of decapitation with five peri-mortem sharp force cut marks on the posterior parts of the cervical vertebrae, and another one on the right second metacarpal. Microscopic observation of the kerfs, the historical records and archaeological evidence support the speculation that the individual could be a warrior of Chu State, who is decapitated after being wounded during the war against the Qin State. The hacking implement and the sequences of the cut marks are further discussed to reconstruct the process of execution. This multidisciplinary reconstruction is the first scientific osteological analysis of the decapitation on the human remains from the Chinese Bronze Age. Moreover, it will enrich our knowledge of the decapitation phenomenon in terms of war and execution in ancient China.
\end{abstract}

Keywords Decapitation $\cdot$ Peri-mortem cut mark $\cdot$ Tomahawk $\cdot$ Cervical vertebrae $\cdot$ Warring States Period of China

\section{Introduction}

Decapitation, in other terms, beheading, is a pervasive worldwide ancient practice which is implemented in different cultural contexts as a cultural phenomenon or social behavior (Aldhouse-Green 2006; Armit 2012; Chacon and Dye 2007; Pearson 2005). Anthropological and historical records have provided several social reasons that may have motivated the ante- or post-mortem head removal in different individual circumstances and cultural contexts (Carty and Gleeson 2013; Harman et al. 1981; Buckberry 2008; Borsje 2007; Boylston et al. 2000; Buckberry and Hadley 2008). By severing the head from the body, decapitation could be a ritual mortuary

Hui-Yuan Yeh

hyyeh@ntu.edu.sg

Qun Zhang

zhang.qun@ntu.edu.sg

1 History College, Zhengzhou University, 100 Science Ave, Zhengzhou 450001, Henan, China

2 Anhui Institute of Cultural Heritage and Archaeology, 469 Cuiwei Road, Hefei 230601, Anhui, China

3 School of Humanities, Nanyang Technological University, 48 Nanyang Ave, Singapore 639818, Singapore practice in order to destroy the soul; a consequence of armed confrontation to kill the foe; a form of trophy to dishonor the dead; a form of sacrifice and a consequence of judicial executions (Philpott 1991; Carty 2015). In order to distinguish and identify the motivation behind the decapitation, it will be an effective way to combine the osteological evidence with the archaeological and historical contexts in which they occur (Carty 2015).

The removal of heads is recognized as early as in the Neolithic period (Simmons et al. 2007; Talalay 2007). In the Levant of the northern Syria, the postmortem decapitation is implemented using stone tools during the early Pre-Pottery Neolithic period, roughly $12,000-10,500 \mathrm{BP}$ as a ritual mortuary practice before the body was totally decomposed (Kanjou et al. 2015). In America, the case study of the earliest mortuary ritualized decapitation could be dated back to cal. 9100-9400 BP which is found in east-central Brazil (Strauss et al. 2015). And in Capsian of Algeria in North Africa, decapitation is also observed dating to cal. $8000 \mathrm{BP}$, which is attributed to either utilitarian or ritual purposes (Haverkort and Lubell 1999). More recently, decapitation burials have been identified more frequently from the Bronze Age to the early modern period in the Europe (Philpott 1991; Müldner et al. 2011; Bush and Stirland 1991; Mckinley 1993; Anderson 2001; Pitts et al. 2002; Carty 2015; Kozakaite et al. 2018; 
Gardeła 2013; Ström 1942; Tucker 2012, 2015; Harman et al. 1981; Armit 2006; Tracy and Massey 2012), the Near East (Dolce 2018), the America (Moser 1973; Lessa 2007; Chacon and Dye 2007; Tung 2008; Conlee 2007; Valdez 2009; Proulx 1971, 1999, 1989; Browne et al. 1993; Verano 2001, 2003), and the Asia (Krohn 1927; Hutton 1928; Gohain 1977; Morimoto 1987; Morimoto and Hirata 1992; Tillema 1989; Phelan 1994; Hoskins 1996; Needham 1976; Nagaoka and Hirata 1992; Lee et al. 2017; Nagaoka et al. 2009) attributed to the interpersonal conflict, cult of the head, and headhunting rite. The portability and importance of a severed head makes it an ideal trophy of war to display one's status, power of heroism, and prowess, harvests, rebirth, and military supremacy, and is considered as a military merit with an honor to be knighted and gifted (Ó Donnabháin 1995, 2011; Goldsworthy 1996; Carty 2015; Ogburn 2007; Proulx 2001; Petersen and Crock 2007; Toyne 2011). Besides, decapitation is frequently employed during the medieval and early modern period in Europe as a form of judicial execution (Waldron 1996).

Decapitation has been recorded in ancient Chinese historical documents for a long time. All types of decapitation have been identified in archeological discoveries (Qian 1994; Sun 1998). During the Neolithic period, ritual skulls are found buried under the foundation of the houses and rampart or in the individual sacrifice pits in Banpo site, Wangchenggang site, Yinjiacheng site, and Shimao site in Shaanxi, Henan, Shandong provinces (Jin 2005; Chen et al. 2016). Besides, headless skeletons are also found in burials in Beishouling site, Liuwan graveyard, Gamatai site, and Dahecun site in Shaanxi, Qinghai, Henan provinces, which could be attributed to sacrifice, conflict, or headhunting rite (Jin 2005; Wang 2015). During the Shang Dynasty in the Bronze Age, thousands of skulls and headless skeletons of young males are found in the sacrifice pits or burials, which are located close to the Kings' tombs in the last capital of the dynasty ( Jin 2005; CASS 1977). Notably, the severed skulls are found in the bronze sacrificial vessels as grave goods (Sun 2015). Meanwhile, from the Zhou Dynasty to Ming Dynasty, another type of decapitation is implemented by the victors of the war. The heads of their enemies are collected as trophies to construct a mound named "Jinguan" or the skulls are made into cups to show military achievement and express contempt to the enemies (Zhou 2005; Zhu 2011; Shi 1996; Zhao 1996; Zhao and Wang 2016; Shi and Song 1996). Even till recently, the headhunting rite is still preserved in some ethnic minorities as a sacrificial ritual in Southwest China in Yunnan province (Li 1987; Wang 1994).

In 2011, a high-status tomb dating back to the Bronze Age is scientifically excavated in Lu'an, Anhui province, which is the last capital of the Chu State called "Shou Chun" during the Late Warring States Period in China (Qin 2012). Warring States Period at the late phase of Chinese Bronze Age is a crucial transformative period as wars and conflicts between different principalities constantly occurred during this period of ancient Chinese history. The well-preserved headless skeleton in this tomb represents one of the most complete and recognizable decapitation cases during that period in China. Although there are abundant archaeological discoveries related to the ancient Chinese decapitation, however, due to the poor preservation and the insufficient awareness in the past, no scientific osteological analysis has ever been conducted regarding the reconstruction of ancient Chinese decapitation. The archaeological excavation of M585 provides a valuable opportunity to look into the phenomenon of ancient execution in China. By analyzing the morphology and direction of the cut marks on the skeleton, the aim of the present study is to speculate the hacking implement and to reconstruct the process of execution, which will contribute to our understanding of the cause of death, the lethal implement, and the process of the decapitation, and further enrich our knowledge of the decapitation phenomenon in terms of war and execution in ancient China.

\section{Materials and methods}

Tomb M585 (N 31 $76^{\prime} 92^{\prime \prime}$, E $\left.116^{\circ} 55^{\prime} 28^{\prime \prime}\right)$ is located on the hummock in the central region of Bailuzhou in Lu'an City of Anhui province (Fig. 1). It is an earthen pit tomb with a path leading to a grave. The structure of the tomb is designed as one outhouse and one chamber with three layers of coffins, which are maintained in good condition. The outhouse is a square chamber which surrounded the inner chamber; the inner chamber is a rectangular space containing the three layers of coffins. The grave goods of the tombs are rich and diverse consisting of bronze, pottery objects, and lacquer wares. Among them, some military implements such as one set of lacquered armor, bronze sword, axe, and other types of weapon are buried along with the burial of M585. The inner coffin is immersed with dark brown liquid, and the human remains immersed in the liquid are found to be in black color distributed haphazardly in the coffin, and the skull is not found inside. The skeleton is in good condition and about $90 \%$ of the skeleton is present for examination (Fig. 2).

The skeleton is laid out in anatomical position. The sex and age of the individuals are determined based on skeletal remains utilizing pubic symphysis, cranium, and dental wear (Périer 1949; Smith and Knight 1984; Brooks and Suchey 1990; Buikstra and Ubelaker 1994). The skeletal traumas are examined using various scientific techniques. Macroscopic observation is focused on the anatomical location, shape, and dimensions of the skeleton, and microscopic observation is focused on the morphology and edges of the cut marks, 


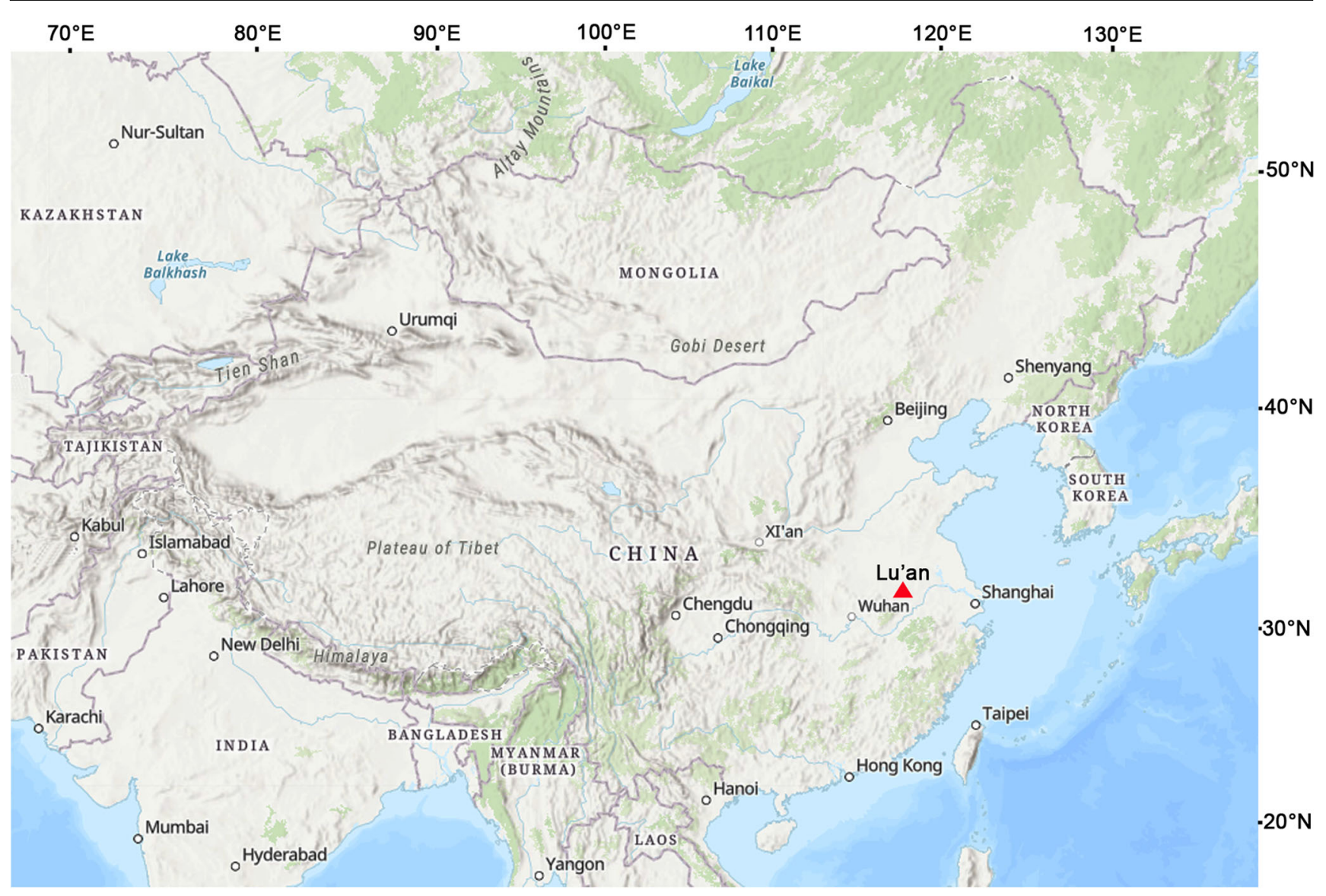

Fig. 1 The location of the archeological site

attempting to detect the condition of healing, if any. The details of the osteological cut marks on cervical vertebrae and metacarpal are observed and measured by using the highresolution deep-field microscope (VHX-2000 series, Keyence, Japan).

\section{Results}

The individual is identified as a male adult at the age of about 35 to 39 with clear evidence indicating the presence of implied decapitation. Based on the macroscopic observation, the individual of the tomb M585 is headless with five obvious sharp
Fig. 2 The tomb onsite and the human remains of the individual of M585 (phalanges were completely preserved but not laid out)

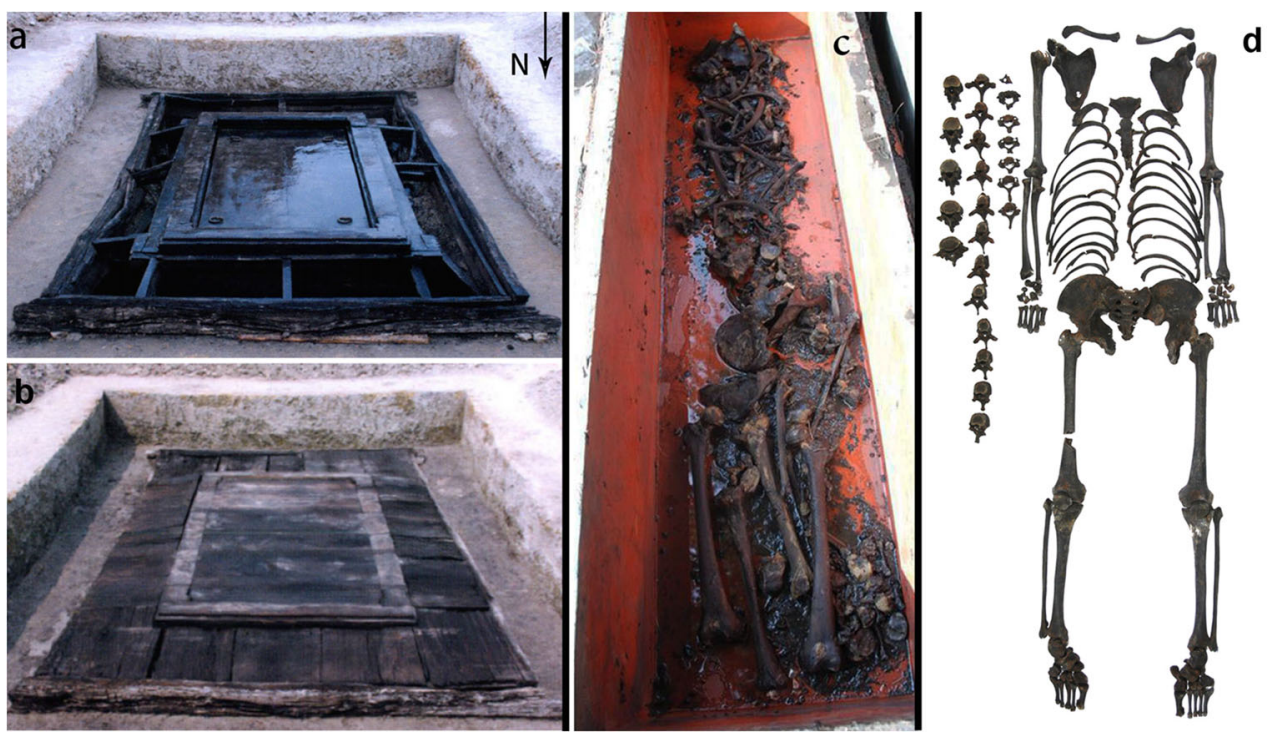


force cut marks on the cervical vertebrae and another one on the right second metacarpal. These cuts on the vertebrae were mainly located on the posterior parts of the axis, atlas, and the third cervical vertebra. Among the five cut marks, three of them were superficial in a nearly horizontal direction; the other two were much deeper in a direction from right to left inferior-superiorly. The cut marks were neat with no taphonomic damage, periosteal reaction, or healing signs observed, indicating that they were received peri-mortem (Sauer 1998). According to the experimental studies of traumatic morphology (Walker and Long 1977; Greenfield 1999), the microscopic profiles of the cut marks made by metal implements tend to be steep and smooth in V-shaped cross-section with a distinct apex. Microscopic observation of the cut marks revealed the vertically straight kerf wall and combined "V" and "U"-shaped cross-section, indicating the presence of cut marks left behind by large bladed implement in a hacking or chopping motion (Fig. 3). The precise measurements of each cut were listed in Table 1.

The cut marks on the vertebrae are characterized by straight and narrow kerf clustered on the atlas, axis, and the third cervical vertebra. Cut one is a fairly shallow straight kerf located at the superior lamina beneath the right superior articular facet on the third cervical vertebra; cut two is a slightly deeper straight kerf located at the superior lamina of axis on the right; cut three is a long disconnected straight kerf through the anterior surface of the vertebral foramen beneath the odontoid process on the axis, which left two deeper marks on the right and left ends and a relatively shallow mark in the middle. These three kerfs are superficial in depth in a nearly horizontal direction. Another two cut marks differ in angle to those superficial ones and are in a direction from right to left inferiorsuperiorly. Cut four is at an angle through the superior lamina of the third cervical vertebra and across the inferior part of the spinous process of axis, penetrating $0.65 \mathrm{~mm}$ into the vertebral body on the axis and removing the right superior articular facet, the uncinate process of the third cervical vertebra, and part of the spinous process and lamina of axis; cut five truncated the odontoid process from the axis and most part of the atlas, leaving the remaining the flat cut surface with trabecular bone exposed (Figs. 4 and 5). Except for the above ones observed on the cervical vertebrae, another cut mark is observed on the superior surface of the second metacarpal on the right hand as a defensive wound. It is $5.13 \mathrm{~mm}$ in length and $1.16 \mathrm{~mm}$ in width. The force is coming from distal and applied on the hand horizontally (Fig. 6).

\section{Discussion}

\section{The recognition of identity and decapitation}

Decapitation usually results in characteristic damage to the skeleton. Normally, as the execution of decapitation is implemented with the blow struck from back to front, it would produce traumatic lesions affecting the posterior parts of the cervical vertebrae with cut marks. It can be confirmed by observing that one or more cervical vertebrae has been transected or left with cut marks, even sometimes with additional damage to the mandible, the mastoid processes, or the first rib (Waldron 1996). In the present case, five obvious perimortem sharp force cut marks were observed on the posterior parts of the axis, atlas, and the third cervical vertebra. Among the five cut marks, three of them were superficial in a nearly horizontal direction, and the other two were much deeper in a direction from right to left inferior-superiorly. Besides, a perimortem sharp force trauma is also observed on the metacarpal. The metacarpal is easily damaged in conflict, indicating that this cut mark is received during the war as a defensive trauma before the victim is captured. All these osteological evidence demonstrate that this individual was decapitated soon after he got injured during the war.

The archaeological findings support the speculation that the identity of the individual is a high-ranking warrior of the Chu state (Qin 2012). The tomb is structured in high-status configuration and the abundant grave goods indicating the high social status of the individual. The historical records $<$ Xunzi-Etiquette $>$ indicates that "Ten layers of coffins for the King, five layers of coffins for the marquis, triple layers of coffins for the senior official, and double layers of coffins for the general official." As to the grave goods, the historic records <Etiquette of Zhou $>$ indicates that "Ding is a privileged sacrificial vessel for the nobles to claim the identity, nine Dings for the King, seven Dings for the marquis, five Dings for the senior official, and three or one Ding for the general official." The triple-layer coffins of M585 with four
Table 1 Measurements of the cut marks on the cervical vertebrae

\begin{tabular}{llllll}
\hline & Morphology & Length & Minimum width & Maximum width & Depth \\
\hline Cut 1 & Linear & $8.29 \mathrm{~mm}$ & $/$ & $/$ & $/$ \\
Cut 2 & Linear & $7.93 \mathrm{~mm}$ & $0.17 \mathrm{~mm}$ & $0.76 \mathrm{~mm}$ & $/$ \\
Cut 3 & Linear & $29.84 \mathrm{~mm}$ & $0.05 \mathrm{~mm}$ & $0.86 \mathrm{~mm}$ & $/$ \\
Cut 4 & Linear and plane & $/$ & $0.69 \mathrm{~mm}$ & $5.35 \mathrm{~mm}$ & $0.65 \mathrm{~mm}$ \\
Cut 5 & Plane & $/$ & $/$ & $/$ & $/$ \\
\hline
\end{tabular}




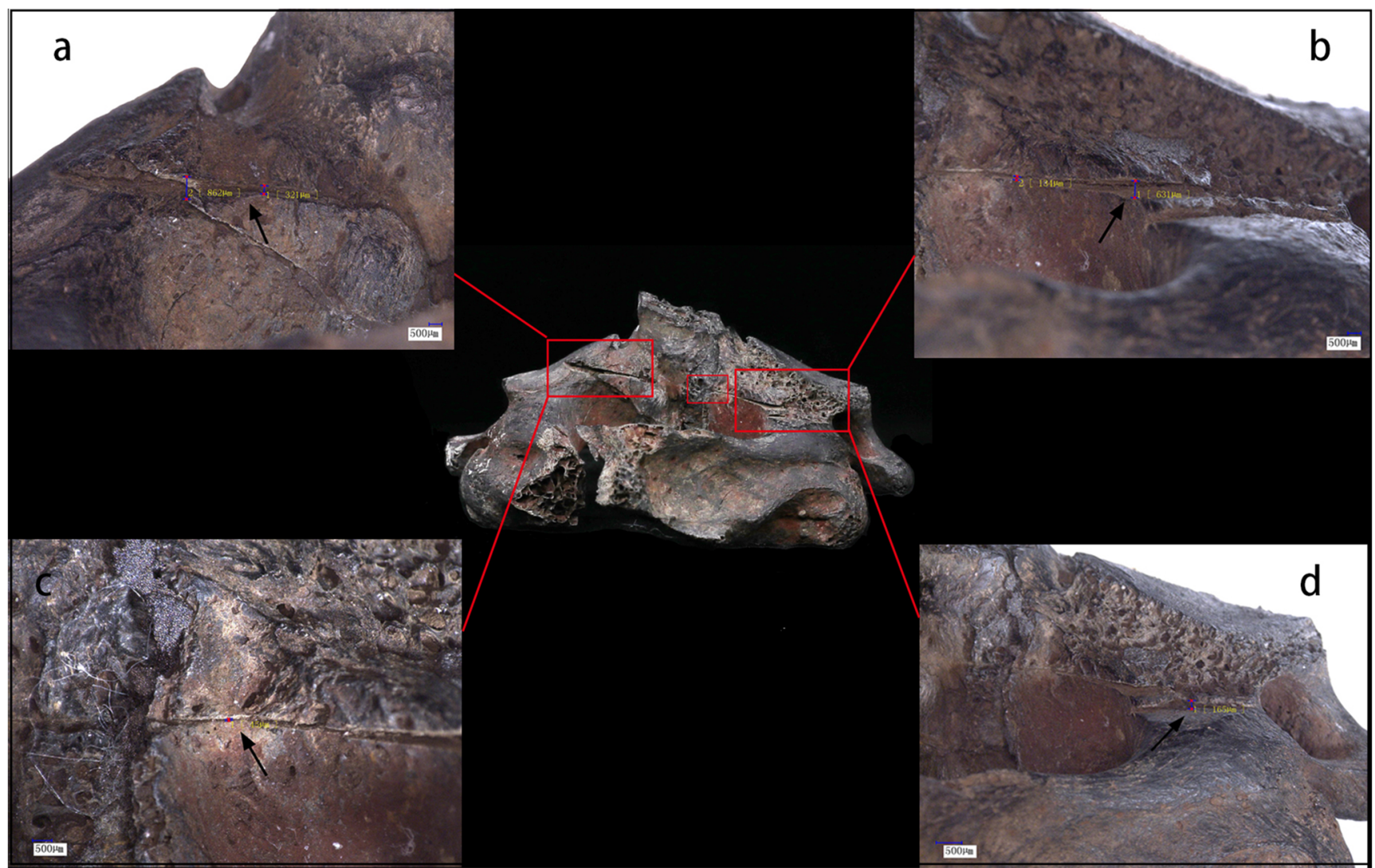

Fig. 3 Microscopic observation of the cut marks on the axis by the high-resolution microscope

Dings revealed the senior official identity of the individual. Moreover, several valuable equipments and weapons including armor, copper sword, and bronze daggers further support the speculation of the identity of warrior (Qin 2012).

Fig. 4 Illustration of the five cut marks on the cervical vertebrae (A posterior view; B superior view; $C$ illustrated in the anatomical model)

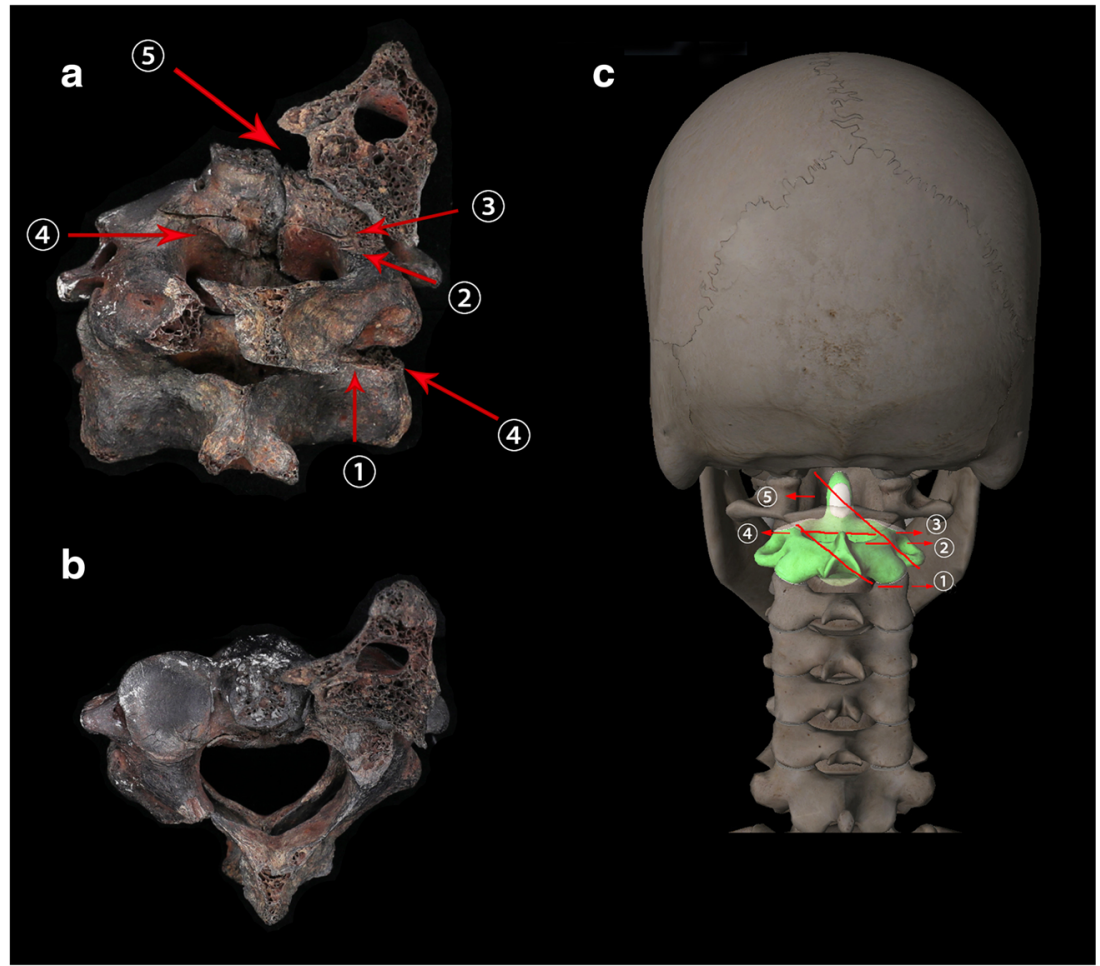


Fig. 5 Cut marks on the atlas, axis, and the third cervical vertebra

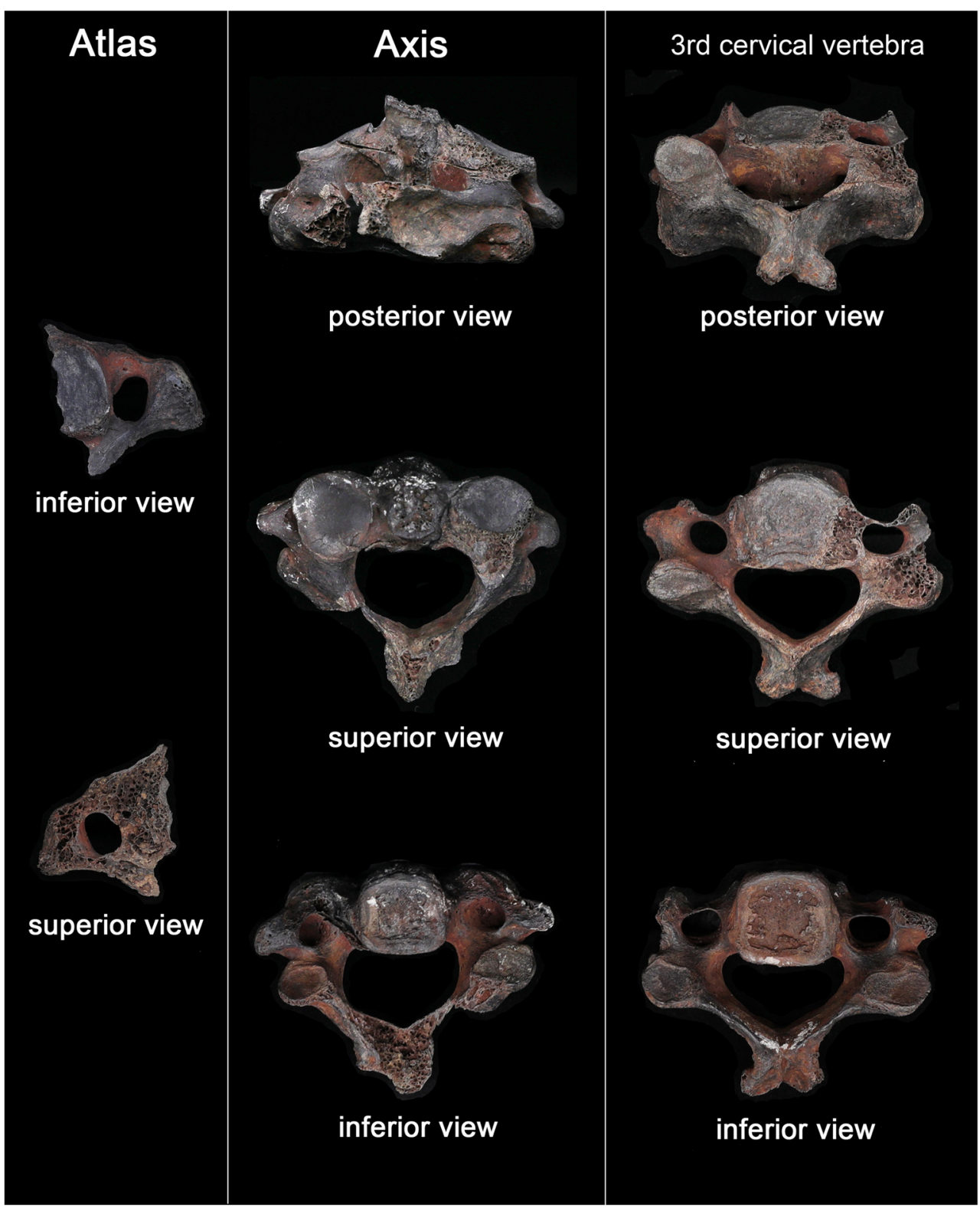

The location of the tomb and the period also contribute to our recognition of the individual's identity. Lu'an is located within the territory of the last capital of Chu State during the Late Warring States Period, when the Chu State is defeated by the Qin State. The Qin State is a powerful principality with strong military forces during that period. Among the principalities during the Warring States Period, the military reward policy of Qin State is closely related to the decapitation which encouraged the soldier to earn military merit and a promotion by decapitating more enemies ( $\mathrm{Fu} 2008$ ). According to the historical records, the Qin State implemented more than 1.7 million decapitations during the twenty-two wars against the Wei States, Zhao State, and Chu State between 364 and 234 BC (Fu 2008; Wang 1957). Among them, the war with Zhao State occurred in $260 \mathrm{BC}$ resulted in the fall of the
Changping city with four hundred thousand decapitations (Wu 2015). The remains of the war was identified in 1995 in Shanxi province, and one of the mass graves contained 130 skulls of male adult with traumas (Shi 1996). These historical records and archaeological evidence demonstrate the prevalence of decapitation during that period and the individual of M585 is extremely likely the victim during the war between the Chu State and the Qin State.

\section{The speculated weapon used for the decapitation}

Normally, decapitation leaves evidence of a cut mark on the bone, indicating that a heavy implement is involved. The osteological evidence and the characteristics of cut marks provide direct clues for the speculation of the implement of 
Fig. 6 Cut marks on the second metacarpal on the right hand

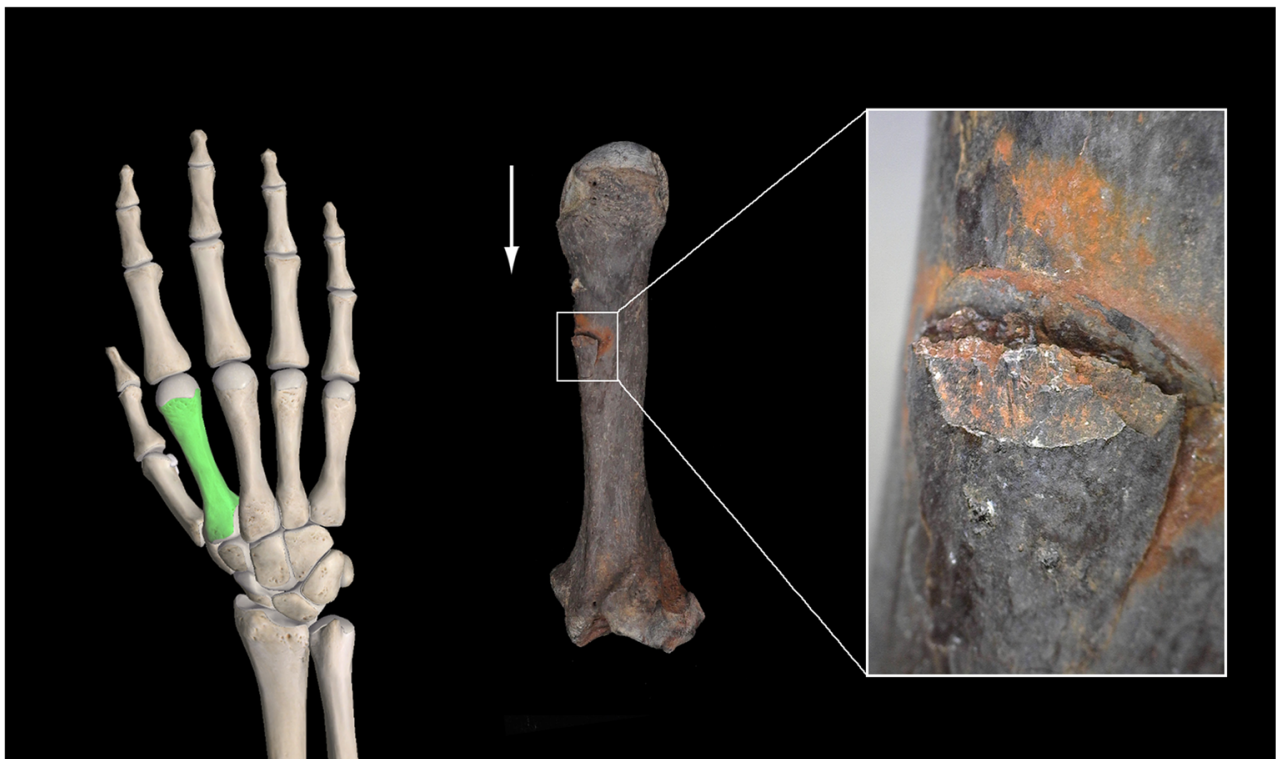

execution. Through visual observation, the margins of the five cut marks on the cervical vertebrae were relatively neat and sharp, with no bone breakdown at the edges and a very thin inner diameter, with the thinnest part being only $0.045 \mathrm{~mm}$. It showed that the cutting edge of the implement used is sharp and is wielded in a high velocity. By observing the bronze lance and sword excavated from the Warring States Period, the cutting edge of the lance is too thick to produce a sharp force trauma with such a thin inner diameter; meanwhile, the sword is basically straight in cutting edge, which could not matched with the cut marks observed on the cervical vertebrae. Given the information, a simulated experiment is conducted by using cardboard to simulate the implement used for the execution. The third cut mark is a hack across the axis posterior-anteriorly which is deep on the left and right ends and shallow in the middle. The right side is deeper than the left side, proving that the force applied on the right side is greater than on the left side. The difference between the depths of the cut mark is attributed to the edge shape of the implement. Two small pieces of rectangular and cambered cardboard with a thickness less than $0.02 \mathrm{~mm}$ were used to simulate the implement applied on the cut mark separately. The rectangular cardboard straight failed to fit the cut mark but the cambered one did (Fig. 7). When the edge of the cambered cardboard touched the kerf floor of cut mark on the left and right ends, the edge of the middle part just applied on the vertebral body superficially. This explained that the cutting edge of the implement which caused this cut mark is not straight but in a cambered shape so as to form that characteristic of cut mark.

In view of hacking implements being relatively understudied (Humphrey and Hutchinson 2001; Lewis 2008; McCardle and Stojanovski 2018), the speculation of implement should be associated with records regarding the likely weapon used during that period. The continual war during the
Warring States Period contributed to the development of weapon innovation and manufacturing technology. The bronze sword, spear, halberd, axe, tomahawk, and dagger are common hand-held weapons used during the Zhou Dynasty. Among the popular hand-held weapons during that period, the edge shape of the implement, which could have caused the cut marks on the cervical vertebrae, is closest to the edge shape of tomahawk. The shape of the tomahawk is in an axe shape with thin and arc-shaped edge which has been used as either a weapon or implement of execution since the Neolithic period (Yang 2003). The stone tomahawk is found during the Neolithic Age, and the bronze tomahawk has first appeared during the Xia Dynasty and became a symbolic implement of kingship and military power during the Shang Dynasty and the Zhou Dynasty (Yang 2003; Qian 2009). During the Warring States Period in China, the prevalence of tomahawk faded during the war due to its large size and weight but was kept as a ceremonial implement during the military operations and weapon of execution for the nobilities (Yang 2003; Qian 2009). Besides, the early Chinese inscriptions carved on oracle bones and bronze vessels during the Shang and Zhou Dynasty reveal the execution of decapitation and the function of tomahawk as well (Li 2012; Rong 1985). The ancient Chinese character of chop call "Zhan (斩)" is consist of a headless person with a tomahawk (Fig. 8). This evidence strongly supported the speculation that the tomahawk is a possible implement for execution used for the decapitation in this case.

\section{Reconstruction of the process of decapitation}

Generally, the blow of decapitation comes from the direction which depends on the dominant hand of the executioner or the direction that the victim is facing. The force of the blow and 


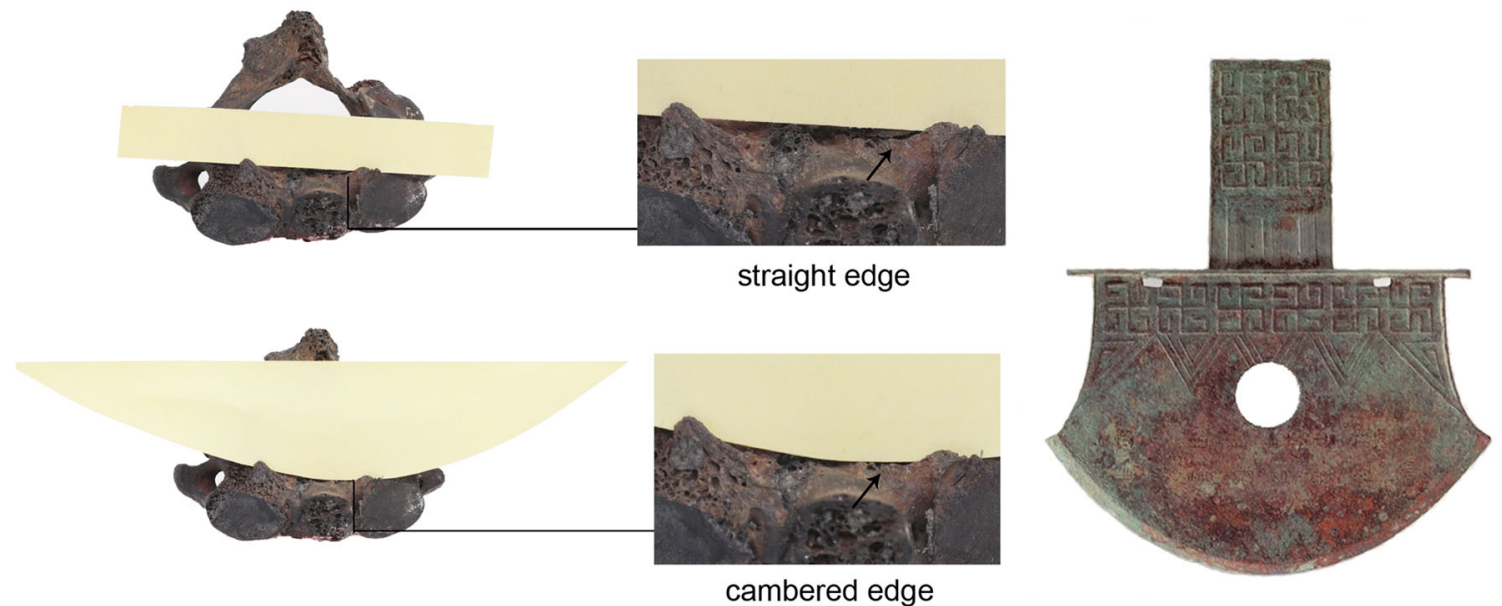

Fig. 7 The simulated experiment of the possible implement (tomahawk) on the axis

the weight of the implement create several kerfs to sever the muscles and ligaments, and then remove the head from the body. However, the cut marks of decapitation provide limited information regarding the timing and sequences of the head removal. Although five cut marks on the atlas, axis, and third cervical vertebra indicated that the cuts were made with a narrow blade posterior-anteriorly, the sequences of the chops were still unclear. Generally, the removal of the head from the body occurs along the mid-cervical region. In order to remove the head at this portion, it is necessary to cut through most of the soft tissues on the neck, and then, tilt the head back as far as possible to conduct the decapitation (Mckinley 1993).

By observing and analyzing the cut marks on the cervical vertebrae, the process of decapitation could be reconstructed based on locations and directions of the cut marks. Based on the location of the cut marks on the cervical vertebrae, the first cut mark is formed at the third cervical vertebra, which resulted in the severing of the longus colli and attached ligaments. Furthermore, the executioner moved the implement forward to the axis and inflicted the second chop. This chop cut off the
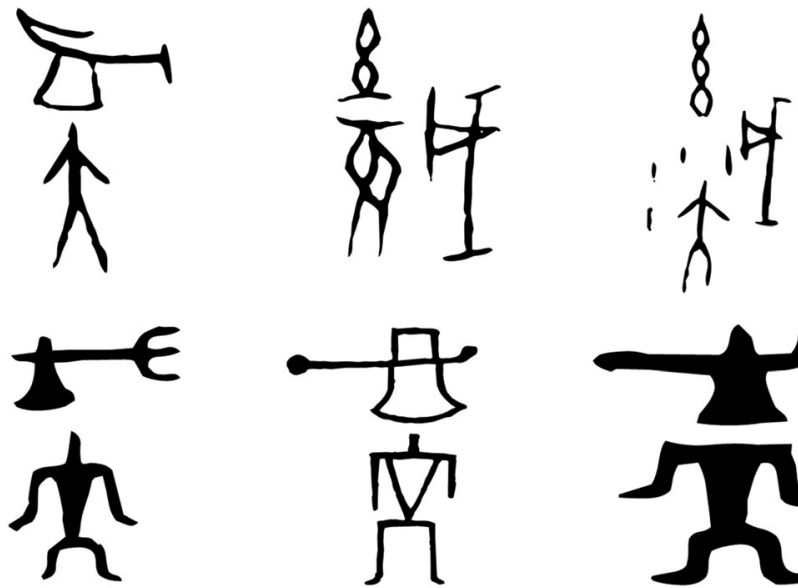

Fig. 8 The characters related to "chop" meaning in ancient Chinese inscription (top: oracle bone script; below: bronze script) rectus capitis anterior, which located at the right side of the cervical vertebra, resulting in a deeper mark on the axis. Hence, the third chop resulted in the death of the individual, which cut through the vertebral foramen and damaged the spinal cord. The first three chops were relatively straight, indicating that the individual is in a position with his head lowered when being executed, whereby the executioner is standing in a higher position than the victim to wield the implement. The fourth and fifth cut marks were in a direction slightly from the right to the left inferior-superiorly. The cut marks on the inferior right is deeper than on the superior left, indicating that the vertebra on the right inferiorly is the location where the force first applied. The executioner is speculated standing on the left side of the victim, wielding the implement with two hands.

The first three cut marks led to the separation of the muscles, ligaments, and blood vessels at the neck and resulted in the individual's death. Observing from the remaining parts of the atlas and axis, only right transverse foramen and part of the anterior arch of the atlas were remained; the transverse foramen of the atlas is located superior to the transverse foramen of the axis on the left, indicating that the victim's head is turned to the left when the fourth and fifth chop performed. To summarize, in the commissions of execution, the process of the decapitation started with the victim kneeling down, drooping his head, and exposing the neck. The executioner is standing on the left side of the victim and performed the decapitation by using the tomahawk (Fig. 9). Three chops led to the death of the individual, and another two chops were performed with the assistance of another executioner holding the victim's head to the left. The last two chops were performed with greater strength to severe the head from the torso completely. It is worth noting that the location of the decapitation of this case is so high up on the neck, which is quite different from the other decapitation locating at a much lower location as C4-C6 (Harman et al. 1981; Bush and Stirland 1991; Waldron 1996; Pitts et al. 2002; Strauss et al. 2015). 


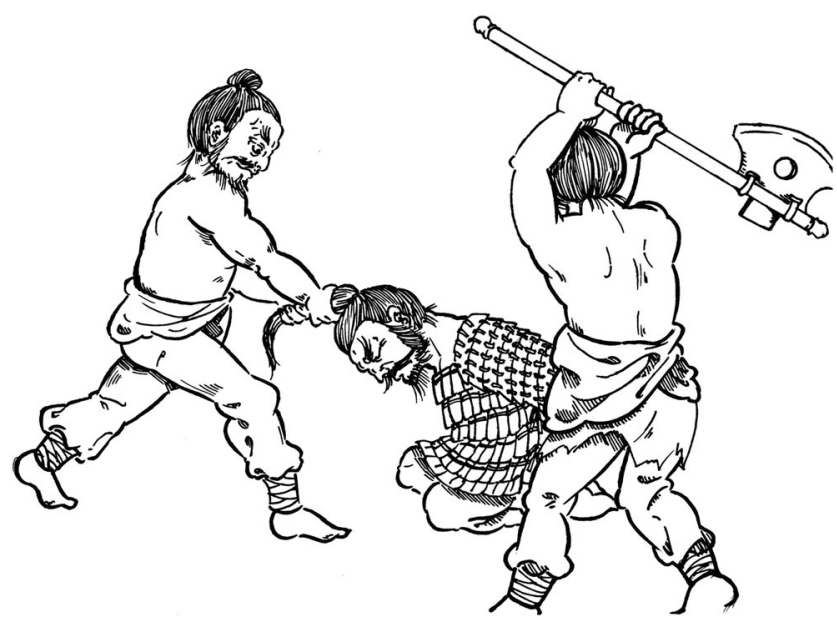

Fig. 9 The sketch of the scenario of decapitation

This could be related to the position of the victim and the special implement being used.

\section{Conclusion}

Decapitation is a pervasive practice in ancient human societies throughout history. Although abundant historical records and some possible related archeological discoveries on decapitation have been recognized in Asia, especially in China, the scientific osteological analysis of the ancient practice is far less adequate. In the present study, a headless skeleton from a high-status noble's tomb in east China is identified as a victim of decapitation and further examined to reconstruct the process of execution in Bronze Age China for the first time. Five peri-mortem sharp force cut marks were observed on the posterior parts of the axis, atlas, and the third cervical vertebrae, and another one on the right second metacarpal. Combining the historical records, archaeological evidence, and the osteological characteristics, the identity of the individual could be a warrior of Chu state, who is decapitated during the war against the Qin State. The tomahawk is a possible implement used for the execution of decapitation, and the sequences of the cut marks and process were further discussed. The first three chops led to the severing of the muscles, ligaments tissue at the neck, and resulted in the individual's death, and another two chops severed the head from the torso completely. The results not only enrich our knowledge of the decapitation phenomenon in terms of war and execution, but also allow a better understanding of the history of ancient China.

Acknowledgments This research is supported by the NAP Start-Up Grant from Nanyang Technological University; the research on the roots of Chinese civilization of Zhengzhou University (Grant No. XKZDJC202006); the sub-project of the Major Project of the National Social Science Fund of China (Grant No. 19ZDA227); the Youth Project of the National Social Sciences Fund of China (Grant No. 17CKG021); the sub-project of the Central Plains Civilization Exploration Project in Henan Province (Grant No. 24220078); the 57th batch of the China Postdoctoral Science Fund (Grant No. 2015 M572113); the open research project of the Key Laboratory of the Ministry of Education of Cultural Heritage Research and Protection Technology of Northwestern University (Grant No. xbdx2019-5-18).

\section{Compliance with ethical standards}

Conflict of interest The authors declare that they have no conflict of interest.

Open Access This article is licensed under a Creative Commons Attribution 4.0 International License, which permits use, sharing, adaptation, distribution and reproduction in any medium or format, as long as you give appropriate credit to the original author(s) and the source, provide a link to the Creative Commons licence, and indicate if changes were made. The images or other third party material in this article are included in the article's Creative Commons licence, unless indicated otherwise in a credit line to the material. If material is not included in the article's Creative Commons licence and your intended use is not permitted by statutory regulation or exceeds the permitted use, you will need to obtain permission directly from the copyright holder. To view a copy of this licence, visit http://creativecommons.org/licenses/by/4.0/.

\section{References}

Aldhouse-Green M (2006) Dying for the Gods: human sacrifice in Iron Age and Roman Europe. Tempus, Stroud, pp 93-110

Anderson T (2001) Two decapitations from roman Towcester. Int J Osteoarchaeol 11:400-405

Armit I (2006) Inside Kurtz's Compound: headhunting and the human body in prehistoric Europe. In: Bonogofksy M (ed) Skull collection, modification and decoration. British Archaeological Reports International Series 1539, Archaeopress, pp 1-14

Armit I (2012) Headhunting and the body in Iron Age Europe. Cambridge University Press, Cambridge

Borsje J (2007) Human sacrifice in medieval Irish literature. In: Bremmer JN (ed) The strange world of human sacrifice. Peeters, Leuvan, pp $31-54$

Boylston A, Knüsel CJ, Roberts CA (2000) Investigation of a RomanoBritish rural ritual in Bedford, England. J Archaeol Sci 27:241-254

Brooks S, Suchey JM (1990) Skeletal age determination based on the Os pubis: a comparison of the Acsádi-Nemeskéri and Suchey-Brooks methods. Hum Evol 5:227-238

Browne DM, Silverman H, Garcia R (1993) A cache of 48 Nasca trophy heads from Cerro Carapo, Peru. Lat Am Antiq 4:274-294

Buckberry J (2008) Off with their heads: the Anglo-Saxon execution cemetery at Walkington Wold, East Yorkshire. In: Murphy EM (ed) Deviant burial in the rchaeological record. Oxbow Books, Oxford, pp 148-169

Buckberry J, Hadley DM (2008) An Anglo-Saxon execution cemetery at Walkingdon Wold, Yorkshire. Oxf J Archaeol 26(3):309-329

Buikstra JE, Ubelaker DH (1994) Standards for data collection from human skeletal remains. Arkansas Archaeological Survey Research Series 44. Fayetteville, Arkansas.

Bush H, Stirland A (1991) Romano-British decapitation burials: A comparison of osteological evidence and burial ritual from two cemeteries. L' Anthropologie 29:205-210

Carty N (2015) The Halved Heads': osteological evidence for decapitation in Medieval Ireland. Pap Instit Archaeol 25(1):1. https://doi.org/ $10.5334 /$ pia. 477 
Carty N, Gleeson P (2013) Kingship, violence and Loch Da Gabhor: royal landscapes and the production of authority in Early Medieval Brega. Ríocht na Midhe 24:29-72

CASS (1977) Excavation of the sacrifice pit of Yin ruins in Anyang. Archaeology 1:20-36

Chacon RJ, Dye DH (2007) The taking and displaying of human body parts as trophies by Amerindians. Springer, New York

Chen L, Xiong JX, Shao J, Sun ZY (2016) Study on skulls unearthed from the sacrifice pit at the site of Shenmu Shimao in Shaanxi. Archaeol Cultural Relics 04:134-142

Conlee CA (2007) Decapitation and rebirth: a headless burial from Nasca, Peru. Curr Anthropol 48(3):438-445

Dolce R (2018) "Losing One's Head" in the Ancient Near East: Interpretation and meaning of decapitation (Studies in the History of the Ancient Near East). Routledge, London/New York

Fu JC (2008) The Decapitation of Qin State. Hist Teach 04:109-111

Gardeła L (2013) The Headless norsemen: decapitation in Viking Age Scandinavia. In: Gardeła L, Kajkowski K (eds) The head motif in past societies in a comparative perspective. Druk, Bytów

Gohain BC (1977) Human sacrifice and head-hunting in North-Eastern India. Lawyer's Book Stall. Assam, pp 26 58(69):41-43

Goldsworthy AK (1996) The Roman army at war: 100 BC-AD 200. Clarendon Press, Oxford, pp 271-276

Greenfield HJ (1999) The origins of metallurgy: distinguishing stone from metal cut-marks on bones from archaeological sites. J Archaeol Sci 26:797-808

Harman M, Molleson TI, Price JL (1981) Burials, bodies and beheadings in Romano-British and Anglo-Saxon cemeteries. Bull Br Museum Nat History (Geology) 35(3):145-188

Haverkort CM, Lubell D (1999) Cutmarks on capsian human remains: implications for Maghreb Holocene social organization and palaeoeconomy. Int J Osteoarchaeol 9:147-169

Hoskins J (1996) Introduction: headhunting as practice and as trope. In: Hoskins J (ed) Headhunting and the social imagination in Southeast Asia. Stanford University Press, Stanford, pp 1-49

Humphrey JH, Hutchinson DL (2001) Macroscopic characteristics of hacking trauma. J Forensic Sci 46(2):228-233

Hutton JH (1928) The significance of head-hunting in Assam. J R Anthropol Inst 58:399-408

Jin HB (2005) Human head worship and related issues in the prehistoric to Shang and Zhou dynasties. Folk Stud 04:89-111

Kanjou Y, Kuijt I, Erdal YS, Kondo O (2015) Early human decapitation, $11,700-10,700 \mathrm{cal}$ BP, within the pre-pottery Neolithic Village of Tell Qaramel, North Syria. Int J Osteoarchaeol 25:743-752

Kozakaite J, Girčius R, Dementavičienè J, Jankauskas R, PiombinoMascali D (2018) Four cases of beheading from 14th-17th century Lithuania. Anthropol Anz 75(3):243-249

Krohn WO (1927) In Borneo jungles: among the Dyak headhunters. Gay and Hancock, London, pp 271-285

Lee H, Oh CS, Hong JH, Kim J, Han L, Park JM, Shin DH (2017) The presence of sharp-edged weapon related cut mark in Joseon skull discovered at the 16th century market district of Old Seoul City ruins in South Korea. Anat Cell Biol 50(4):306-309

Lessa A (2007) Rituais de sacrifício: a sobrevivência de uma antiga dimensão do corpo humano. História, Ciências Saúde-Manguinhos 14:907-919

Lewis JE (2008) Identifying sword marks on bone: criteria for distinguishing between cut marks made by different classes of bladed weapons. J Archaeol Sci 35(7):2001-2008

Li JS (1987) Religion in the prehistoric headhunting customs. J Lit Hist 02:31-33

Li ZK (2012) Compilation of the inscriptions carved on oracle bones (JiaGuWenZiBian). Zhonghua Book Company Beijing, pp 95, 1252.

McCardle P, Stojanovski E (2018) Identifying differences between cut marks made on bone by a machete and katana: a pilot study. J
Forensic Sci 63:1813-1818. https://doi.org/10.1111/1556-4029. 13754

McKinley JI (1993) A decapitation from the Romano-British cemetery at Baldock, Hertfordshire. Int J Osteoarchaeol 3:41-44

Morimoto I (1987) Note on the technique of decapitation in medieval Japan. J Anthrop Soc Nippon 95(4):477-486

Morimoto I, Hirata K (1992) A decapitated human skull from medieval Kamakura. J Anthrop Soc Nippon 100(3):349-358

Moser CL (1973) Human decapitation in Ancient Mesoamerica. Studies in pre-Columbian art and archaeology, no. 11. Dumbarton Oaks, Washington, pp 1-2 4-72

Müldner G, Chenery C, Eckardt H (2011) The 'Headless Romans': Multi-isotope investigations of an unusual burial ground from Roman Britain. J Archaeol Sci 38:280-290

Nagaoka T, Hirata K (1992) A decapitated human skull from medieval Kamakura. Anthropol Sci 100:349-358

Nagaoka T, Uzawa K, Hirata K (2009) Weapon-related traumas in human skeletons from Yuigahama Chusei Shudan Bochi, Japan. Anat Sci Int 84(3):170-181

Needham R (1976) Skulls and causality. Man 11:71-88

Ó Donnabháin B (1995) Monuments of shame: some probable trophy heads from medieval Dublin archaeology Ireland 9(4):12-15.

Ó Donnabháin B (2011) The social lives of severed heads: skull collection and display in medieval and Early Modern Ireland. In: Bonogofsky M (ed) The bioarchaeology of the human head. University Press of Florida, Miami, pp 122-138

Ogburn D (2007) Human trophies in the late pre-Hispanic Andesstriving for status and maintaining power among the Incas and other societies. In: Chacon RJ, Dye DH (eds) The taking and displaying of human body parts as trophies by Amerindians. Springer, New York, pp 505-522

Pearson MP (2005) The archaeology of death and burial. Texas A\&M University Press, College Station, p 17

Périer AL (1949) Usure, abrasion, erosion. Pratique OdontoStomatologique 140:1-7

Petersen JB, Crock JG (2007) "Handsome death": the taking, veneration and consumption of human remains in the insular Caribbean and greater Amazonia. In: Chacon RJ, Dye DH (eds) The taking and displaying of human body parts as trophies by Amerindians. Springer, New York, pp 547-574

Phelan PR (1994) The Magang ceremony and head-hunting. The Sabah Museum, Kota Kinabalu

Philpott R (1991) Burial practices in Roman Britain: a survey of grave treatment and furnishing A.D. 43-410. In: British Archaeological Reports (British Series), vol 219. Tempus Reparatum, Oxford, pp 305-309

Pitts M, Bayliss A, McKinley J, Bylston A, Budd P, Evans J, Chenery C, Reynolds A, Semple SJ (2002) An Anglo-Saxon decapitation and burial at Stone henge. Wiltshire Archaeol Nat Hist Mag 95:131-146

Proulx DA (1971) Headhunting in ancient Peru. Archaeology 24(1):1621

Proulx DA (1989) Nasca trophy heads: victims of warfare or ritual sacrifice? In: Tkaczuk DC, Vivian BC (eds) Cultures in conflict: current archaeological perspectives. Archaeological Association of the. University of Calgary, Calgary, pp 73-85

Proulx DA (1999) Nasca headhunting and the ritual uses of trophy heads. In: Rickenbach J (ed) Nasca: Geheimnisvolle Zeichen im alten Peru. Museum Rietberg Zurich, Zurich, pp 79-87

Proulx DA (2001) Ritual uses of trophy heads in ancient Nasca society. In: Benson EP, Cook AG (eds) Ritual sacrifice in ancient Peru. University of Texas Press, Austin, pp 119-136

Qian YP (1994) Study on the decapitation rite in prehistory China. Archaeol Cult Relics 04:41-47

Qian YP (2009) Preliminary study on the Chinese axe and tomahawk. Acta Archaeol Sin 01:1-34 
Qin RP (2012) The excavation of the Tomb M585 during the Warring States Period in Bailuzhou, Lu'an of Anhui Province. Archaeology 11:23-32

Rong G (1985) Compilation of the inscriptions carved on bronze vessels (JinWenBian). Zhonghua Book Company, Beijng, p 1029

Sauer NJ (1998) The timing of injuries and manner of death: distinguishing among antemortem, perimortem, and post mortem trauma. In: Reichs KJ (ed) Forensic osteology: advances in the identification of human remains, 2nd edn. Charles C Thomas, Springfield, pp 321-332

Shi YS (1996) Preliminary analysis on the classification of the large and medium tombs in Yanxiadu - discussion on the period and identity of the human skull burials. J Cult Relics of Liaohai 02:24-45

Shi JM, Song JZ (1996) Excavation report of the Yonglu No. 1 human remains pit of the Changping Battle site. Cult Relics 06:33-40

Simmons T, Goring-Morris N, Horwitz L (2007) "What ceremony else?" Taphonomy and the ritual treatment of the dead in the Pre-Pottery Neolithic B mortuary complex at Kfar HaHoresh, Israel. In: Faerman M, Horwitz LK, Kahana T, Zilberman U (eds) Faces from the past: diachronic patterns in the biology and health status of human populations from the eastern Mediterranean. BAR int. ser. 1603. Archaeopress, Oxford, pp 1-27.

Smith BG, Knight JK (1984) An index for measuring the wear of teeth. Br Dent J 156:435-438

Strauss A, Oliveira RE, Bernardo DV, Salazar-García DC, Talamo S, Jaouen K et al (2015) The oldest case of decapitation in the New World (Lapa do Santo, East-Central Brazil). PLoS One 10(9): e0137456 https://doi.org/10.1371/journal.pone.0137456

Ström F (1942) On the sacral origin of the Germanic death penalties. Håkan Ohlssons Boktryckeri, Lund, p 162

Sun QG (1998) An ethnographic examination of the headless burials found in archeology. J Natl Museum Chin Hist 02:85-97

Sun M (2015) On the beheading sacrifice custom in Shang Dynasty. Yindu Journal 36(04):9-14

Talalay LE (2007) Heady business: skulls, heads, and decapitation in Neolithic Anatolia and Greece. J Mediterr Archaeol 17:139-163

Tillema HF (1989) A journey among the peoples of Central Borneo in word and picture. Oxford University Press, Oxford, p 241

Toyne J (2011) Interpretations of pre-hispanic ritual violence at Tucume, Peru, from cut mark analysis. Lat Am Antiq 22:505-523

Tracy L, Massey J (eds) (2012) Heads will roll: decapitation in the Medieval and Early Modern Imagination. Brill, Leiden
Tucker K (2012) The osteology of decapitation burials from Roman Britain: a post-mortem burial rite? In: Smith MJ, Knüsel C (eds) The Routledge handbook of the bioarchaeology of human conflict. Routledge, London

Tucker K (2015) An archaeological study of human decapitation burials. Pen and Sword, Barnsley

Tung TA (2008) Dismembering bodies for display: a bioarchaeological study of trophy heads from the Wari site of Conchopata, Peru. Am J Phys Anthropol 136:294-308

Valdez LM (2009) Walled settlements, buffer zones, and human decapitation in the Acari Valley, Peru. J Anthropol Res 65(3):389-416

Verano JW (2001) The physical evidence of human sacrifice in ancient Peru. In: Benson E, Cook A (eds) Ritual sacrifice in ancient Peru. University of Texas Press, Austin, pp 165-184

Verano JW (2003) Mummified trophy heads from Peru: diagnostic features and medicolegal significance. J Forensic Sci 48:525-530

Waldron T (1996) Legalized trauma. Int J Osteoarchaeol 6:114-118

Walker PL, Long JC (1977) An experimental study of the morphological characteristics of tool marks. Am Antiq 42:605-616

Wang YZ (1957) Several issues on the social nature of the Western Zhou Dynasty. Aust Hist Stud 8:79-101

Wang SH (1994) Headhunting customs and skull worship among the Wa people in Xilian. Chinese Cult 01:71-77

Wang QQ (2015) A study of the headless burial culture in Prehistoric Qinghai. Qinghai Soc Sci 04:176-180

Wu Q (2015) On the issue of killing prisoners in Ancient China. Cult J 08: 221-223

Yang L (2003) Preliminary study on the development of Chinese axe and tomahawk. Relics Museolgy 02:41-44

Zhao HC (1996) Preliminary analysis on the identity of the human skull burials in Yanxiadu. China's Cult Relics News 1996:2-4

Zhao LY, Wang JX (2016) Preliminary discussion on the identity of the human skull burials in Yanxiadu. Western Archaeol 01:102-112

Zhou JJ (2005) The Jingguan and its historical locus. J Ancient Books Collation 01:83-86

Zhu XH (2011) The phenomenon of Jingguan in Ancient China and its cultural analysis. Soc Sci 09:57-61

Publisher's note Springer Nature remains neutral with regard to jurisdictional claims in published maps and institutional affiliations. 